\title{
Intervention Protocol Based on Transtheoretical Model of Behavior Change for Metabolic Syndrome
}

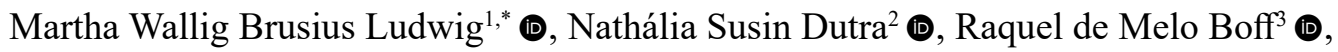 \\ Ana Maria Pandolfo Feoli ${ }^{4}$ (D, Andréia da Silva Gustavo ${ }^{4}$ (D, Fabrício Edler Macagnan ${ }^{5}$ (D, \\ $\&$ Margareth da Silva Oliveira ${ }^{4}$ (1) \\ ${ }^{1}$ Technical Manager at Psicomnutri. Member of the Cefi Contextus Team, Porto Alegre, RS, Brasil \\ ${ }^{2}$ Hospital de Clínicas de Porto Alegre, Porto Alegre, RS, Brasil \\ ${ }^{3}$ Universidade de Caxias do Sul, Caxias do Sul, RS, Brasil \\ ${ }^{4}$ Pontificia Universidade Católica do Rio Grande do Sul, Porto Alegre, RS, Brasil \\ ${ }^{5}$ Universidade Federal de Ciências da Saúde de Porto Alegre, Porto Alegre, RS, Brasil
}

\begin{abstract}
The present study is the translation and adaptation of an intervention based on the Transtheoretical Model of Change directed to patients at cardiovascular risk. The original 29-session manual was translated into Portuguese, extended to 36 sessions, and applied in a pilot study. The protocol was reduced to 12 sessions through the grouping based on the processes of change. The products of the present study were the processes in each behavior, the versatility of the protocol, the interdisciplinary work, the great cost-benefit, and the potential of effectiveness. Finally, the importance of consistent training in Motivational Interview, Transtheoretical Model and group management for proper use are highlighted, and the costs and benefits of protocols versus more flexible treatments are discussed.
\end{abstract}

KEYWORD: Treatment adherence, Transtheoretical model of change, Motivation; Metabolic syndrome, weight loss

\section{Protocolo de Intervenção Baseada no Modelo Transteórico de Mudança de Comportamento para Síndrome Metabólica}

\begin{abstract}
RESUMO - Trata-se da tradução e adaptação de uma intervenção baseada no Modelo Transteórico de Mudança e direcionada para pacientes com risco cardiovascular. Inicialmente o manual original de 29 sessões foi traduzido para a língua portuguesa, ampliado para 36 sessões, aplicado em um estudo piloto. A partir de agrupamentos pelos processos de mudança, o foi reduzido para 12 sessões. Evidencia-se como produtos deste trabalho o aprofundamento dos processos em cada comportamento, a versatilidade do protocolo, o trabalho interdisciplinar, o ótimo custo-benefício e o potencial de efetividade. Por fim, salienta-se a importância de um treinamento consistente em Entrevista Motivacional, Modelo Transteórico e manejo de grupos para utilização adequada do mesmo, e discute-se os custos e os benefícios do protocolos $\mathrm{x}$ tratamentos mais flexíveis.
\end{abstract}

PALAVRAS-CHAVE: adesão a tratamento, modelo transteórico de mudança, motivação, síndrome metabólica, emagrecimento

\section{INTRODUCTION}

Treatment adherence is considered a challenge for patients and professionals and has been the focus of studies with different health disorders, such as hypertension (Araújo, \& Garcia, 2006; Santos et al., 2005), chronic

*E-mail: marthaludwig@hotmail.com

- Submetido: 23/12/2015; Revisado: 05/26/2020; Aceito: 09/18/2020. 
pain (Kurita, \& Pimenta, 2003) and metabolic syndrome (MS) (Busnello et al. 2011). Adhering to the proposed interventions is fundamental for the well-being and for increasing quality of life of patients. In addition, health disorders generate an increase in social costs, as they are often the cause of absenteeism, health care licenses and disability retirement (Santos et al., 2005), which denotes several reasons for the development of strategies that improve treatment adherence, such as the proposal of the protocol presented in this article.

Adherence can be understood as a set of factors, such as attending consultations, adopting a healthy lifestyle, having a commitment to your own health and being the subject of action, that is, everything that characterizes effective engagement in self-care activities (Santos et al., 2005). The authors also point out that clients, when they are adhering to treatment, become multipliers in their family and in their community.

In MS, treatment adherence consists of adopting a healthy lifestyle in order to prevent organic, social and thus psychological complications (Sharovsky et al., 2004). Healthy eating and regular practice of physical exercise are fundamental, once the concomitance of MS with cardiovascular diseases increases approximately 1.5 times the overall mortality and 2.5 times, approximately, the cardiovascular mortality (Sociedade Brasileira de Cardiologia, 2005).

In order to explore and clarify the concept of adherence, a review of the main theories related to health behaviors was carried out. The definition for adherence was the persistence in the practice and maintenance of the desired health behavior, resulting in an active participation and agreement between patient and professional (Cohen, 2009). It should also be emphasized the need for the decision making to be shared between patient and professional (Oliveira, \& Gomes, 2004).

This issue of active collaboration and cooperative work between patient and physician when seeking therapeutic success goes back to the term "collaborative partnership", which is one of the characteristics that composes the "spirit" of the Motivational Interview (MI) proposed by Miller and Rollnick in the 1980s. The MI is the main background of the intervention that originated this article. The authors define MI as "a gentle form of counseling (...)" that "acts by activating patients' own motivation for change and treatment adherence" (Rollnick et al., 2009, p.21).

This "spirit" proposed by the creators of MI consists of four components: (I) collaborative partnership, (II) evocation of the reasons for change, (III) acceptance of clients' autonomy, and (IV) compassion. The collaborative partnership exists to the extent that professional and patient seek for a joint decision-making process, while the evocation of the reasons for change refers to look for the patients' own motivation and resources for change. As a third component, considering the importance of accepting that each person can and should make their own choices, the acceptance / respect for the autonomy of the client allows the understanding that change becomes possible when there is the right and the freedom not to change. Finally, compassion is defined as a fundamentally human atmosphere in which MI should be practiced. Compassion differentiates MI from contexts in which interpersonal influence processes are used, for instance in sales, in marketing and in politics, even if without awareness, and in which compassion would not be at the center (Miller \& Rollnick, 2013).

Although it is necessary, treatment adherence is not easy (Reiners et al., 2008), hence the need to create treatment strategies that address these aspects, highlighting motivation as a relevant component to be further developed. The Transtheoretical Model (TTM) of Behavior Change proposed in 1982 by James Prochaska and Carlo DiClemente contributes to treatments since it offers an integrative structure to understand and intervene in the processes of intentional change. According to Prochaska et al. (2006), interventions that promise to increase adherence need to be multifaceted, including several variables for multiple behaviors, and TTM offers an approach that integrates different approaches in order to understand and intervene in change. The article from 1982 explains the origin of the model, which was born from a comparison of the 18 main psychotherapy systems, in which Prochaska identified 5 basic (change) processes. At that time, the authors described the processes as consciousness raising (feedback, education), conditional stimuli (counterconditioning, stimulus control), catharsis (corrective emotional experiences, dramatic relief), choosing (self-liberation and social liberation), and contingency control (revaluation, contingency management).

The TTM presents, as fundamental aspects, the processes of change and the stages of change. The processes of change are like "the engines of change", which enables the person to move from one stage to another, and it can be divided into two groups: cognitive/experiential processes of change, more characteristic of the initial stages of change (pre-contemplation, contemplation and preparation-PCP); and behavioral processes, which are more frequent in the final stages (action and maintenance - AM). The former is related to the thoughts and feelings that facilitate the change, including: (1) consciousness raising-fundamental in prevention and treatment programs, characterized by awareness about behavior and the need for change; (2) emotional arousal - can highlight/increase the value of the current behavior or the new behavior, as well as decrease their values or their need for these behaviors. Emotional relief interacts and contributes to the processes of awareness enlargement and reassessment processes; (3) self-reevaluation - involves "consideration of how the behavior fits with current or aspirational values, beliefs 
and goals" (DiClemente, 2003, p.34); (4) environmental reevaluation - relates to how the current behavior is useful or profitable in the environment/context in which one lives; (5) social liberation - is characterized by engaging individuals in perceiving and increasing the alternatives and opportunities that help them initiate new habits, and perceive those that facilitate to maintain as it is (Velásquez et al., 2001)

Behavioral processes include: (1) self-deliberation -related to the decision to change and the commitment to modify patterns of behavior in search of a new habit; (2) control or generalization of stimuli - create, change or avoid stimuli that lead to a particular behavior; (3) conditioning or counterconditioning - make new connections between certain stimuli and the behaviors they provoked; (4) reinforcement management - understand, create and change the contingencies of the environment that reinforce the behavior, and (5) aid relationships - also interpreted as social support, has been considered "an important element in initiation, modification, or cessation of behaviors" (DiClemente, 2003, p.35).

The stages characterize the different steps that people go through when they are in a process of intentional change (Prochaska et al.,1992). The pre-contemplation stage concerns the moment when the individual does not recognize a problem, thus not intending to change in the next 6 months. At this stage, the risks associated with the behavior are not identified. When one begins to recognize a problem, but still wants to maintain the same behaviors, we call contemplation, a phase in which ambivalence regarding making changes prevails. The stage of preparation occurs when the individual begins to plan ways to effect a change within the next thirty days, and when the individual effectively takes the first steps it is called the stage of action. The maintenance stage is characterized by change supported for at least six months. These steps are dynamic, do not occur linearly and continuously, but as a spiral in motion and have the processes of change as markers.

Based on these dimensions of the TTM, Velásquez et al. (2001) developed a treatment manual for substance abuse, entitled "Group treatment for substance abuse: a stages-ofchange therapy", which was submitted to translation into Portuguese and adapted for MS with authorization from one of the co-authors (C. DiClemente, 10 de maio de 2009). The original manual for substance abuse has 29 specific sessions and behaviors to be decreased or ceased, varying according to the type of drug and the patient's purpose. According to DiClemente (2003), when addressing behavior change, situations of cessation, modification and initiation are contemplated.

For the treatment of MS, DBSM-I (2005) foresees 11 behaviors that should be observed and modified by patients, such as increasing the consumption of healthy foods (vegetables, fruits, fish, cereals), decreasing unhealthy foods (fats, sugars, etc.), increasing physical activity, as well as starting and maintaining a routine of aerobic exercises 3 to 5 times a week. In the treatment approach of MS, it is noted that it oriented changes in some habits and initiation of others, but not cessation. Furthermore, the orientations are diverse and regard multiple behaviors, which required an adaptation of the original manual.

Since taking action for two or more behaviors can be difficult, Prochaska et al. (2008) argued that changing multiple behaviors represents a special challenge, as it is a stage that demands a lot from the clients. Prochaska and Velicer (1997) pointed out that when individuals present four or more health risk factors (such as smoking, problematic eating behavior, sun exposure and sedentary lifestyle), less than $10 \%$ act for two or more behaviors. These data demonstrate that, even if there are many behaviors to be modified, it is important that both the patient and the professional have clarity about what are the problematic behaviors that are targets of the treatment in order to increase the likelihood for changing adherence. Thus, alternative strategies should aim few problematic behaviors sequentially and simultaneously, and gradually advance on the work with other habits.

Several studies around the world have tested the TTM, recognized worldwide for presenting several empirical evidences of effectiveness for behavior change in general health (Arafat et al., 2016 Menezes et al., 2016;), weight loss (Di Noia \& Thompson, 2012; Han et al., 2015; Mostafavi et al., 2015; Ott et al., 2015; Wu \& Chu, 2015;), promoting healthy eating and adhering to physical activity (Di Noia \& Thompson, 2012; Romain, et al, 2018; Sanaeinasab et al., 2013;). In Brazil, the effectiveness of the TTM for abstinence of crack and cocaine users was evaluated by Szupszynski (2012) and by Rodrigues (2013), with an intervention protocol of eight sessions also adapted from the manual by Velasquez et al. (2001), and the results demonstrated a positive effect regarding readiness for behavior change and maintenance of abstinence in the first 15 days after treatment completion.

Considering its applicability at a national level, the Brazilian National Secretariat for Drug Policies (SENAD, Portuguese acronym) together with the Ministry of Justice (MJ) offer the SUPERA (System for detecting the abuse and dependence of psychoactive substances: Referral, brief intervention, Social Reintegration and Follow-up) course, in which the use of TTM is taught in module no. 4 (Brief Intervention) to engage chemical dependents in treatment. The National Cancer Institute (INCA, Portuguese acronym) also proposes the Booklet on Approach and Treatment of Smokers, an approach to the stages of Motivation for change that composes the theoretical body of the TTM. There are few national studies that have evaluated the TTM to aid the changing eating habits and physical exercise. Nevertheless, the Primary Care notebook of 
the Ministry of Health number 38 (Ministério da Saúde, 2014) that deals with care for people with chronic disease, specifically obesity, recommends that health professionals observe motivational stages to support patients to adhere to healthy eating.

This article aims to present the translation to Portuguese of a treatment manual based on TTM targeting substance addiction and its adaptation to patients at cardiovascular risk (more specifically with MS). In addition, it is our aim to describe the reduction of the original protocol from 29 sessions to a 12 -session protocol. To best of our knowledge, this was the first treatment manual based on the TTM and fully translated into Portuguese. This work was carried out by a team of the research group "Group of Research, Evaluation and Care in CognitiveBehavioral Psychotherapy “, from the Graduate Program in Psychology of PUCRS, in which part of the authors of this article participated.

\section{METHOD}

\section{Portuguese Translation and adaptation of the manual to cardiovascular risk}

The first step in the development of the intervention described in this article was the translation of the original manual "Group treatment for substance abuse: a stagesof-change therapy manual" (Velasquez et al, 2001) of 29 sessions for the Portuguese language. This manual contained 14 sessions related to the stages of pre-contemplation, contemplation and preparation (PCP) and 15 sessions related to the stages of action and maintenance (AM).

After the translation, the target behaviors were adapted, since in the original manual they were related to the use of substances, and in its adaptation would be directed to changes in diet and exercise practice. In addition, some tasks to be developed with patients were modified. This stage had the collaboration of professionals with knowledge about TTM and/or experience with obesity and MS.

Considering that this treatment would be applied in a larger study (MERC Program - Portuguese acronym for Lifestyle Modification and Cardiovascular Risk,) and that it would consist of 36 sessions over a year, the protocol was expanded, consisting of 18 sessions of PCP (during the first six months) and 18 of AM (during the following 6 months). The study consisted of a clinical trial (approved by the Research and Ethics Committee of our University, register with no. 10/05153), in which men and women between 30 and 59 years old diagnosed with MS were randomized into two types of treatment: group modality with the interdisciplinary team, or individual modality with separate consultations with Psychologist, with Nutritionist and treadmill-oriented walks with Physiotherapist. After the first six months, we crossed-over the individuals from the two groups, meaning that those who had started in the group modality would now have individual consultations and vice versa. The study was considered very long and costly. Throughout that year the team worked hard to improve the knowledge and practices regarding the model, and the experience counted as team improvement and pilot intervention for the reduced one described here.

\section{Pilot intervention and adaptation to the interdisciplinary context}

The MERC program intervention team is composed of professionals and students from different health areas: Nutrition, Physiotherapy, Nursing, Pharmacy, and Psychology that was the last area to be included and therefore adapted to the study design. During this first part of the study, in which the intervention lasted one year (36 sessions), the group intervention was composed of a 30-minutes-work focused on health education (at each meeting, about the care of one of the areas - Nutrition, Physiotherapy, Nursing and Pharmacy), and one hour of intervention focused on the processes of change, a moment coordinated/facilitated by a member of the Psychology team. The individual sessions of Psychology followed the same script based on the TTM of the group sessions, not relying on health education.

Throughout this first year of work, the team of psychologists and Psychology students met weekly in order to discuss the applicability and improvement of this protocol. In addition, several trainings on MI (Miller \& Rollnick, 2001) were conducted, because, although the manual used to adapt the intervention did not consist of the MI itself, the effectiveness of the intervention is much greater when the content of the session is permeated by the components of the MI (Velasquez et al., 2001). For this reason, the therapists received 30 hours of supervision and/or training in the motivational approach, and the members of the Nutrition, Physiotherapy, Nursing and Pharmacy teams participated in some of these trainings.

This initial protocol of 36 sessions over one year of intervention was applied to 38 subjects and served as a pilot intervention. This initial experience originated an experience report in relation to the first six months of the intervention (Ludwig et al., 2010a), which focused on the initial stages of change (PCP) in relation to food and physical exercise. 


\section{Reduction of pilot intervention to the reduced version}

In order to make this treatment more applicable, especially in the context of public health, the intervention time was reduced to three (3) months. The development of this reduced treatment protocol in 12 sessions consisted of groupings according to the change processes, so that the 10 processes were maintained. A brief outline of the original sessions and the reduced sessions is illustrated in Table 1, which describes the name of the session, the original sessions that were grouped and that originated the new session, and the process of change evoked in each of them. For example, session 1 of the reduced protocol grouped sessions 1 and 2 of PCP of the original manual and it develops the process of change consciousness raising.

Table 2 illustrates which sessions in the original manual were deleted and why. For example, there were meetings that addressed more significant aspects for the context of chemical dependence than for the context of patients at cardiovascular risk, so they could be removed, such as PCP 3 and PCP 4, illustrated in Table 2. Moreover, considering that the other areas involved in the intervention (Nutrition, Physiotherapy and Nursing) participated in group treatment through workshops or lectures of health education, the processes of change would then be worked on in other ways, different from those described in the original manual. For example, the process of consciousness raising would be explored with a lecture and discussion about what MS is and what its risks are (in the $1^{\text {st }}$ session), as well as through the one-day food record that the nutritionist requested the participants to fulfill. Both activities sought to broaden patients' consciousness of their current pattern of behavior and were combined with the first session of the manual, which aimed at the process of increasing consciousness. Table 2 describes which sessions were removed, the objective each one had, and the reasons for the exclusion.

The treatment protocol as shown in Table 1 went through a consulting of Professor Dr. Carlo DiClemente, resulting in the improvement of some of the materials (activity sheets that are filled by the patient in the session), as well as in the way of working on the processes of change for these specific patients. A much-discussed issue was the need for a greater focus on the conditioning process for those patients who are not yet in action for the target(s) behavior(s), who need to build "cues" to start a new behavior in their lives. For example, in addition to working on the identification of stimuli that precede the lapse or relapse, it is fundamental focusing on the construction of stimuli that serve as cues for the creation of a new habit.

Table 1

Adaptation of the 29 sessions of the original manual into 12 sessions for MS

\begin{tabular}{|c|c|c|c|}
\hline Sessions & Session Name & Original sessions & Change processes evoked \\
\hline Session 1 & The Stages of Change and a typical day & PCP $1+$ PCP 2 & Consciousness raising \\
\hline Session 2 & Expressions of concern and values & PCP6 + PCP7 & Self-reevaluation and Dramatic relief. \\
\hline Session 3 & Relationships and roles & PCP9 + PCP10 & Environmental Reevaluation \\
\hline Session 4 & Pros and Cons & PCP 8 & Decisional Balance \\
\hline Session 5 & Temptation and Confidence & PCP11 + PCP12 & Self-Efficacy \\
\hline Session 6 & $\begin{array}{l}\text { Determining a goal, preparing for change, and } \\
\text { reviewing }\end{array}$ & $\begin{array}{l}\text { PCP13+ } \\
\text { PCP } 14\end{array}$ & Self-liberation \\
\hline Session 7 & $\begin{array}{l}\text { Identifying triggers, managing desires and } \\
\text { impulses, and rewarding successes }\end{array}$ & $\begin{array}{l}\text { AM2 + AM9+ } \\
\text { AM4 }\end{array}$ & $\begin{array}{l}\text { Stimulus Control, Counterconditioning, } \\
\text { Reinforcement Management }\end{array}$ \\
\hline Session 8 & Managing thoughts & AM 8 & $\begin{array}{l}\text { Stimulus Control, Counterconditioning, } \\
\text { Reinforcement Management }\end{array}$ \\
\hline Session 9 & $\begin{array}{l}\text { Effective communication, effective refusals, and } \\
\text { critical management }\end{array}$ & $\begin{array}{l}\text { AM5+ AM6+ } \\
\text { AM7 }\end{array}$ & $\begin{array}{l}\text { Counterconditioning and Reinforcement } \\
\text { Management }\end{array}$ \\
\hline Session 10 & $\begin{array}{l}\text { New ways to enjoy life, social support, needs and } \\
\text { resources }\end{array}$ & AM10 & $\begin{array}{l}\text { Stimulus Control, Counterconditioning, } \\
\text { Reinforcement Management, Help Relations and } \\
\text { Social Liberation. }\end{array}$ \\
\hline Session 11 & $\begin{array}{l}\text { Developing an Action Plan and committing to it } \\
\text { after a lapse }\end{array}$ & AM11 + AM12 & Self-liberation \\
\hline Session 12 & Review and closure & AM15 & Self-Efficacy and Reinforcement Management \\
\hline
\end{tabular}

Note: $\mathrm{PCP}=$ pre-contemplation/contemplation/preparation; $\mathrm{AM}=$ action/maintenance. Content prepared from an adaptation by Velasquez et al. (2001). 
Table 2

Deleted sessions and justifications

\begin{tabular}{|c|c|c|}
\hline $\begin{array}{l}\text { Title and process of change } \\
\text { of the original session } \\
\text { (withdrawal) }\end{array}$ & Purpose of the session & Justification of withdrawal \\
\hline $\begin{array}{l}\text { PCP 3: Physiological effects of } \\
\text { alcohol (consciousness raising) }\end{array}$ & $\begin{array}{l}\text { To verify the extent of alcohol use (AUDIT). } \\
\text { To learn how alcohol can harm their bodies } \\
\text { from a physiological point of view. }\end{array}$ & $\begin{array}{l}\text { The intervention forecasted that each patient would receive } \\
\text { printed blood test results, which were discussed, allowing } \\
\text { them to know the extent of their problem and share with the } \\
\text { group if they wanted to. A printed version of feedback from the } \\
\text { psychology assessment was also delivered to each patient and } \\
\text { discussed. }\end{array}$ \\
\hline $\begin{array}{l}\text { PCP 4: Physiological effects of } \\
\text { drugs (Consciousness raising) }\end{array}$ & $\begin{array}{l}\text { That clients answer a questionnaire } \\
\text { evaluating the extent of the use of the drug(s). } \\
\text { For clients to learn how the drug(s) can } \\
\text { physiologically harm their bodies. }\end{array}$ & $\begin{array}{l}\text { The workshops and lectures throughout the intervention offered } \\
\text { information about MS and its repercussions for health as well } \\
\text { as on the consequences of sedentary lifestyle and of unhealthy } \\
\text { diet. }\end{array}$ \\
\hline $\begin{array}{l}\text { AM 1: The stages of change } \\
\text { (Consciousness raising) }\end{array}$ & $\begin{array}{l}\text { That clients learn the stages of change and } \\
\text { determine in which one they were. }\end{array}$ & $\begin{array}{l}\text { Clients had already learned this in the first session, and stages } \\
\text { were resumed in discussions whenever necessary. }\end{array}$ \\
\hline $\begin{array}{l}\text { AM 3: Handling stress } \\
\text { (counterconditioning) }\end{array}$ & $\begin{array}{l}\text { That clients recognize how much it can affect } \\
\text { the body and behavior to be in stressful } \\
\text { situations. } \\
\text { To learn techniques to act against stress, as it } \\
\text { can be a trigger for use. To practice relaxation } \\
\text { techniques. }\end{array}$ & $\begin{array}{l}\text { The protocol already provided the work on avoiding } \\
\text { and/or managing stressful situations through effective } \\
\text { communication, and through problem solving. In this way, the } \\
\text { counterconditioning was already worked on. }\end{array}$ \\
\hline
\end{tabular}

Note: $\mathrm{PCP}=$ pre-contemplation/contemplation/preparation; $\mathrm{AM}=$ action/maintenance. Content prepared from an adaptation by Velasquez et al. (2001).

\section{RESULTS AND DISCUSSION}

As in the original manual, all sessions have the same structure, which include: the identification of the change processes to be worked on in the session; the theoretical contribution that underpins it; the specific objectives of the meeting and, finally, the explanation of how to develop the session (the 'step-by-step' of what should be accomplished). In addition, the manual has educational materials to be filled out by patients during the session and discussed with the therapist (and/or the group). Table 3 describes the protocol with its refined objectives after consulting, as well as the materials worked on during each session. It was also performed the back-translation of the processes of change for discussion and adequacy of the concepts with Professor Dr. Carlo DiClemente.

As previously stated, each meeting had specific aims and tasks to evoke the corresponding processes of change, which facilitated the professional to keep the focus on the aspects of the model to be worked on. Briefly, the techniques used in the sessions are described in the sequence. Session 1 aimed at psychoeducation regarding the stages, so that the patients could evaluate themselves. Session 2 worked with open questions about people and their own concerns about their health. It created the opportunity for participants to connect with their emotions that arise from their current lifestyle, enabling the participants to see how much it was in agreement with their values or not. In this session, they were also able to look at the image they had of themselves at that moment and the one they would like to have.

Session 3 aimed at psychoeducation regarding the impact of our behaviors on the roles we play as well as on our relationships. Patients used self-monitoring to identify these aspects in their lives. Session 4 worked with cost analysis and benefits of maintaining and changing their lifestyle, while 5 aimed at psychoeducation about self-efficacy and temptation, and used problem solving to risk situations. The sixth session used the technique of behavioral targets, establishing goals and a plan to change, while the seventh followed up to start new behaviors as well as worked on the process of management, using psychoeducation of self-reward.

Session 8 worked on techniques for identifying dysfunctional thoughts that facilitated problematic behaviors, as well as cognitive restructuring, teaching them to respond to thoughts. The ninth session used communication and role-play training to strengthen patients to deal with criticism when they "get out of the diet" and when they refuse foods they would not like to eat. Session 10 worked on programming activities that should forecast feeling pleasure, seeking to increase the behavioral repertoire of patients. The penultimate session reinforced the work on behavioral targets in addition to the prevention of relapse and to the psychoeducation about what to do after a lapse or relapse. The final session used reminder cards to work on reinforcement management and relapse prevention. 
Table 3

Description of the Treatment Protocol

\begin{tabular}{|c|c|c|c|}
\hline Session & Change Process & Session Objectives & Materials to Work With (Records) \\
\hline \multirow[t]{3}{*}{1} & \multirow{3}{*}{$\begin{array}{l}\text { Increased } \\
\text { consciousness }\end{array}$} & - Clients learn the Stages of the Change Model. & The Stages of Change. \\
\hline & & $\begin{array}{l}\text { - Clients complete the exercise to determine their own stage of change } \\
\text { for problem behaviors. }\end{array}$ & Where am I? \\
\hline & & $\begin{array}{l}\text { - Clients reflect on how their days have been, how they have been eating } \\
\text { and how they have been related to the activity and/or physical exercise. }\end{array}$ & \\
\hline \multirow[t]{4}{*}{2} & \multirow{4}{*}{$\begin{array}{l}\text { Self-reassessment } \\
\text { and Emotional } \\
\text { Relief. }\end{array}$} & $\begin{array}{l}\text { - Clients discuss ways in which other people have expressed concerns } \\
\text { about their lifestyle. }\end{array}$ & Expressions of concern and values. \\
\hline & & $\begin{array}{l}\text { - Clients wonder if they themselves have personal concerns about their } \\
\text { lifestyle. }\end{array}$ & \\
\hline & & - To help clients identify their personal values. & \\
\hline & & $\begin{array}{l}\text { - To help clients determine if their personal values are discrepant or in } \\
\text { accordance with their lifestyle. }\end{array}$ & \\
\hline \multirow[t]{5}{*}{3} & \multirow[t]{5}{*}{$\begin{array}{l}\text { Surrounding } \\
\text { Revaluation }\end{array}$} & $\begin{array}{l}\text { - Clients recognize that the behavior can affect several areas of their life } \\
\text { (personal, professional, leisure, etc.). }\end{array}$ & Relationships and roles \\
\hline & & $\begin{array}{l}\text {-Clients identify current and potential relationships, and think about } \\
\text { whether the unhealthy lifestyle can harm relationships with others. }\end{array}$ & \\
\hline & & $\begin{array}{l}\text { - Clients discuss whether their relationships have changed due to } \\
\text { unhealthy lifestyle. }\end{array}$ & \\
\hline & & - Clients identify the roles they play in life. & \\
\hline & & - Clients recognize how the unhealthy lifestyle has affected such roles. & \\
\hline \multirow[t]{2}{*}{4} & \multirow[t]{2}{*}{ Pros and cons } & - Clients learn how to identify the pros and cons of behavior. & - My pros and cons of poor diet. \\
\hline & & - Clients learn how to attach importance to the pros and cons. & - My pros and cons of not exercising. \\
\hline \multirow[t]{4}{*}{5} & \multirow[t]{4}{*}{ Efficacy } & $\begin{array}{l}\text { - Clients identify situations in which they are more tempted to get out of } \\
\text { the diet and not exercise. }\end{array}$ & - Temptation and confidence in food. \\
\hline & & $\begin{array}{l}\text { - Clients seek to increase their confidence about their ability to stay on } \\
\text { the diet and exercise even in tempting situations. }\end{array}$ & $\begin{array}{l}\text { - Temptation and confidence for } \\
\text { Physical Exercise. }\end{array}$ \\
\hline & & $\begin{array}{l}\text { - Clients discuss the implications of various levels of temptation and } \\
\text { trust. }\end{array}$ & - Examples of problem solving. \\
\hline & & $\begin{array}{l}\text { - Clients learn to think about problems and review an example of how to } \\
\text { solve problems. }\end{array}$ & - Description of your problem. \\
\hline \multirow[t]{4}{*}{6} & \multirow[t]{4}{*}{ Self-deliberation } & - Clients learn about how to set appropriate goals. & $\begin{array}{l}\text { - Determination of objectives and } \\
\text { change plan }\end{array}$ \\
\hline & & - Clients create declared aims and a plan to change to achieve those aims. & - My goals and my plan of change \\
\hline & & - Clients review the topics seen during the course of the group. & - Review \\
\hline & & - Clients discuss changes and the progress they have made. & $\begin{array}{l}\text { - Cards with several achievements } \\
\text { or successes of each of the group } \\
\text { members during the course, to be } \\
\text { delivered to them. }\end{array}$ \\
\hline \multirow[t]{8}{*}{7} & \multirow{8}{*}{$\begin{array}{l}\text { Conditioning, } \\
\text { Stimulus Control, } \\
\text { Counterconditioning, } \\
\text { Reinforcement } \\
\text { Management }\end{array}$} & - Clients create "clues" to start new health behaviors & - My "clues" to start new behaviors \\
\hline & & $\begin{array}{l}\text { - Clients identify situations or emotions that are a trigger to get out of the } \\
\text { diet or not exercise. }\end{array}$ & $\begin{array}{l}\text { - When am I more tempted to get out } \\
\text { of the diet? }\end{array}$ \\
\hline & & $\begin{array}{l}\text { - Customers create appropriate ways to avoid or to change these } \\
\text { "triggers". situations }\end{array}$ & $\begin{array}{l}\text { - When am I more tempted not to } \\
\text { exercise? }\end{array}$ \\
\hline & & $\begin{array}{l}\text { - Clients discuss desires and impulses, identify the differences among } \\
\text { them. }\end{array}$ & - Handling Impulses and Desires \\
\hline & & $\begin{array}{l}\text { - Clients learn how to replace desires and impulses with positive/ } \\
\text { functional thoughts and behaviors. }\end{array}$ & - Rewarding My Success \\
\hline & & - Clients understand the importance of gratifying positive behaviors. & - When am I more tempted to get out \\
\hline & & - Clients identify recent achievements. & of the diet? \\
\hline & & - Clients have ideas on how to reward their positive behaviors. & \\
\hline
\end{tabular}




\begin{tabular}{|c|c|c|c|}
\hline Session & Change Process & Session Objectives & Materials to Work With (Records) \\
\hline 8 & $\begin{array}{l}\text { Stimulus Control, } \\
\text { Counterconditioning, } \\
\text { Reinforcement } \\
\text { Management. }\end{array}$ & $\begin{array}{l}\text { - Clients identify how thoughts can generate temptation to get out of the } \\
\text { diet and to not exercise. } \\
\text { - Clients learn techniques on how to manage their thoughts. }\end{array}$ & $\begin{array}{l}\text { - Identifying and challenging } \\
\text { maladaptive thoughts. }\end{array}$ \\
\hline 9 & $\begin{array}{l}\text { Counterconditioning } \\
\text { and Reinforcement } \\
\text { Management }\end{array}$ & $\begin{array}{l}\text { - Clients learn three communication styles (passive, aggressive, and } \\
\text { assertive). } \\
\text { - Clients determine their typical ways of communicating with others. } \\
\text { - Clients learn tools to communicate effectively. } \\
\text { - Clients think of people who often eat poorly and/or are sedentary, and } \\
\text { who can offer you foods out of diet or who can encourage them not to } \\
\text { exercise. } \\
\text { - Clients practice skills to refuse offers to get out of the diet or to not } \\
\text { exercise. } \\
\text { - Clients learn how to receive, appropriately, criticism from others. } \\
\text { - Clients learn techniques to criticize others constructively and } \\
\text { effectively. }\end{array}$ & $\begin{array}{l}\text { - Effective Communication } \\
\text { - Practicing Refusals } \\
\text { - Handling Reviews }\end{array}$ \\
\hline 10 & $\begin{array}{l}\text { Stimulus Control, } \\
\text { Counterconditioning, } \\
\text { Reward } \\
\text { Management, Help } \\
\text { Relations and Social } \\
\text { Deliberation. }\end{array}$ & $\begin{array}{l}\text { - Clients identify healthy activities that can be pleasurable } \\
\text { - Clients identify potential problems in performing these activities and } \\
\text { solutions to these potential problems. } \\
\text { - Clients identify potential sources of social support, understand its } \\
\text { importance and learn how to develop it. } \\
\text { - Clients identify areas of life that have not been fully developed or that } \\
\text { have been harmed due to an unhealthy lifestyle. } \\
\text { - Clients identify locations for information and assistance to develop } \\
\text { these areas. }\end{array}$ & $\begin{array}{l}\text { - New ways to enjoy life } \\
\text { Who and what can help me? } \\
\text { - Needs and resources }\end{array}$ \\
\hline 11 & Self-Deliberation & $\begin{array}{l}\text { - Clients review strategies to maintain the behaviors they started. } \\
\text { - Clients plan management strategies if they resume their old lifestyle. } \\
\text { - Clients choose the best strategies according to their personality. } \\
\text { - Clients understand that relapses and lapses are a part of any behavior } \\
\text { change. } \\
\text { - Clients create ideas/strategies on how to resume lifestyle change (diet } \\
\text { and exercise adhering) after a lapse. }\end{array}$ & $\begin{array}{l}\text { - Review } \\
\text { - My action plan } \\
\text { - "What can I do after a lapse?" }\end{array}$ \\
\hline 12 & $\begin{array}{l}\text { Self-Efficacy and } \\
\text { Reinforcement } \\
\text { Management }\end{array}$ & $\begin{array}{l}\text { - Clients review the topics worked on during the course of the group. } \\
\text { - Clients discuss the changes and progress they have made. } \\
\text { - Clients engage in closure activities. }\end{array}$ & $\begin{array}{l}\text { - Cards with messages prepared by } \\
\text { you, in advance for each client, that } \\
\text { list several achievements or successes } \\
\text { achieved by them during the course of } \\
\text { the group. } \\
\text { - "Review" Leaflet }\end{array}$ \\
\hline
\end{tabular}

Note: Content prepared from an adaptation by Velasquez et al. (2001).

The 12 sessions with the evoked processes and the materials for each meeting have already been presented in congresses: V Day of Cognitive Therapy (Ludwig et al., 2013), IV International Seminar on Social Skills (Oliveira et al., 2013) and VII Iberoamericano Congreso de Psicología Clínica y de la Salud (Oliveira et al., 2012), $7^{\text {th }}$ World Congress of Behavioral and Cognitive Therapies (Szupzinsky, Rodrigues, Ludwig, Souza, Oliveira, Boff, $\&$ Susin, 2013), and X Brazilian Congress of Cognitive Therapies (Ludwig et al., 2015), in which the demand for knowing in detail the methodology of this adaptation was raised and it is being described in this material.

One of the results of the doctoral dissertation (Ludwig, 2012), that originated this reduced protocol, showed that the self-efficacy to maintain diet and exercise after the treatment were predictors of weight reduction in the whole sample. A follow-up study of this protocol, in which 55 patients were reevaluated, demonstrated a significant effect of time $(\mathrm{p}=0.001)$ with weight reduction, Body Mass Index (BMI), abdominal circumference and blood pressure. Significant 
differences $(p=0.001)$ were found between the groups that were submitted to the protocol (group and individual intervention) in comparison with those who received the standard intervention, in which the experimental groups were able to maintain weight reduction. In addition, these groups obtained a significant weight reduction when comparing initial evaluation and follow-up (Susin et al., 2014).

A sub-analysis study of the randomized clinical trial, in which this reduced protocol was applied, sought to identify the impact of 3 types of intervention for patients with MS on the Casteli Index. This index is a score that identifies increased risk for cardiovascular events and can be used to verify the effects of lifestyle changing interventions. The results showed that the experimental groups, that received the intervention (also consisted of the protocol described here), obtained absolute variations and significant percentages, while the standard intervention had unfavorable results (Feoli et al., 2018).

In what regards the application of the intervention, it should be highlighted, among the challenges encountered, the occasional difficulty of therapists to the structure of the protocol, once patients sometimes preferred to talk about other issues of their life instead of the behaviors related to lifestyle. Even though it was explained since the first session that the aim of the meetings would be to work on their behavioral changing processes related to food and exercise (if they thought that change was necessary - here the MI as a background), a few patients sought to prioritize other problems of their lives. For instance, one of the patients reported, during the reassessment at the end of the intervention, having liked the therapist very much, but perceived the meetings as "boring", because "we always had to talk about diet and exercise, everything we do not want to talk about".

In this context, there is a discussion of the costs and benefits of manualized vs flexible interventions. The American Psychology Association (APA) in 2006 created in the meeting of several clinical scientists and psychologists, the Task Force on Evidence Based Practice (Tse-Bp), which brings evidence-based psychology as a combination of technical skill of the practitioner and the best available evidence. If, on the one hand, the protocols aim to offer evidence-based treatments hence ensuring their effectiveness, on the other hand, there is the risk of the professional disregarding peculiarities of that person, if it becomes too centered on the protocol. We do not question the importance of Psychology and Psychiatry seeking to ensure the quality of the care provided avoiding practices based on intuition, but rather we intend to draw attention to the possible risk of this bias, once there are many other variables that affect the outcomes of the studies (Ludwig et al., 2010b; Melnik \& Atallah, 2011), and that some professionals do not have the technical skills to make protocols more flexible according to the client's needs.

In the specific context of TTM-based interventions, in cases in which changes are required in more than one problematic behavior of the client, the therapist should consider that the patient may be in a more advanced stage of change in one behavior than the other. In this case, the therapist approach should change according to the moment of patient's readiness stage, since, according to TTM, experiential-cognitive processes should be primarily evoked when the patient is in the initial stages of change, while behavioral processes should be used with caution (Ludwig, 2017). Thus, if the professional is very focused on the processes and little focused on the patient, he/she may use strategies that do not agree with the patient's need. In this sense, DiClemente (2017) states that both researchers as well as clinicians and professionals in general should keep their focus on the patients and their processes, not only on the developed interventions and the sought results.

Finally, it is emphasized that this protocol can be used by professionals who have sufficient knowledge of the TTM, through study, practice and supervision, and who understand not only about stages of change, but also about experiential-cognitive and behavioral processes. In addition, professionals should have skills in MI, since the way of talking with the patient has as background the "spirit" of MI. It is also necessary to know well behavioral and cognitive techniques, such as psychoeducation, identification and recording of dysfunctional thoughts, problem solving, costbenefit analysis, reminder cards, self-monitoring, behavioral targets, among others. Also, for the group modality, we highlight the need for good training in group processes as well as in care and management of groups.

\section{FINAL CONSIDERATIONS}

This article aimed to describe the process of translation to Portuguese and adaptation of an intervention based on the TTM originally developed for substance users (Velasquez et al., 2001) for the population with MS. The protocol was reduced from 29 to 12 sessions, the first six working on the initial stages of change and the final six on the most advanced stages. This protocol covers the 10 change processes proposed by the TTM and proposes aims and tasks to be developed at each session, and it can be applied individually or in groups.

The process of adaptation of the protocol as well as its final product highlights important aspects, such as the nuances between the processes of change of different behaviors, the work perspective that knowledge about the TTM enables health professionals, its versatility to work with other health-related problems both individually and in 
groups, the interdisciplinary contexts in which it can be used, its low cost and the potential for its effectiveness.

Among the important aspects that were evidenced and that bring contributions to professional practice as well as theoretical contributions, the adaptation of the manual allowed discussing the peculiarities in the processes of change for the two different types of population. For instance, it drew attention of the Psychology team that drug addiction presents very different impairments from those found in MS, because in the former there are more marked problems related to job loss, interpersonal relationships and constant financial problems. In MS, the most pronounced harm to patients is related to their own health and aesthetics. Some examples were back pain due to lack of exercise and physical activity and feeling unattractive in personal life.

Another relevant aspect was the surrounding reassessment process. As mentioned earlier, this process involves recognizing the impacts that problematic behavior has on the environment. In working with substance abuse, this process aims to make it more evident to patients that drug use has negative consequences not only for themselves, but for their relationship with others, family, work and social life in a very significant way (Velasquez et al., 2001). In the experience with patients with MS, patients often reported that their poor diet and sedentary lifestyle hardly affected other people. When asked about the consequences of their behaviors in their relationships, they reported that the opposite occurred more commonly, that is, the fact that they were taking care of food and performing physical exercises made the others praise them and learn healthy behaviors with them. Patients who were having more difficulty changing reported that what they perceived was people's concern with their health.

Considering that the understanding of the concepts of the TTM broadens the knowledge of the health professional about human motivation and the process of change, and it can instrumentalize them in favor of the patients' adherence to healthier behaviors, this protocol can be a possible pathway to the applicability of knowledge consequently decreasing behaviors harmful to health.

Regarding the versatility of the protocol, although originally developed for group treatment, the authors themselves mention that the sessions can be easily adapted to the individual modality (Velásquez et al., 2001). In addition, this protocol can be applied in other populations that aim to reduce weight and/or adhering to a healthier lifestyle, such as in people with obesity, diabetes, dyslipidemia, etc., even though it has been adapted and used for patients with MS.

Furthermore, the protocol can be used in an interdisciplinary way, and this work showed that the intervention with the TTM, focusing on the processes of change and with the structure that the model offers, facilitates communication among the team, because the other areas better understand the work of Psychology, as well as have an opportunity to learn to increase the patients' motivation. The sessions have a goal to be worked on, and present the process of change as a background, guiding the interventions of the professional in order not to lose the focus of the work. Also, in this sense, the treatment protocol is very positive.

Another important aspect is that the reduction of the treatment protocol from one year to three (3) months facilitates its application in the public health network, and the fact that the work can be done in groups makes it possible to care for a greater number of people. Thus, this treatment proposal presents a viable cost-benefit ratio, besides an important potential for effectiveness, as stated in the studies mentioned above and that used the protocol. Further studies should be conducted comparing the effects of this intervention with others that also aim adherence to new behaviors.

\section{REFERENCES}

American Psychological Association (2006). Evidence-based practice in psychology: APA presidential task force on evidence based practice. American Psychologist, 61(4), 271-285.

Arafat, Y., Mohamed Ibrahim, M. I., \& Awaisu, A. (2016). Using the transtheoretical model to enhance self-management activities in patients with type 2 diabetes: A systematic review. Journal of Pharmaceutical Health Services Research, 7(3), 149-156. doi:10.1016/j.jval.2015.09.2152

Araújo, G. B. D. S., \& Garcia, T. R. (2006). Adesão ao tratamento anti-hipertensivo: Uma análise conceitual. Rev. eletrônica enferm, 8(2), 259-272.

Ministério da Saúde. Secretaria de Atenção à Saúde. (2014). Estratégias para o cuidado da pessoa com doença crônica: Obesidade. Cadernos de Atenção Básica, $n^{0} 38$. http://189.28.128.100/dab/docs/portaldab/publicacoes/ caderno_38.pdf

Busnello, F. M., Bodanese, L. C., Pellanda, L. C., \& Santos, Z. E. A. (2011). Intervenção nutricional e o impacto na adesão ao tratamento em pacientes com síndrome Metabólica. Arq. Bras. Cardiol., 97(3), 217-224.
Cohen, S. M. (2009). Concept analysis of adherence in the context of Cardiovascular Risk Reduction. Nursing Forum, 44, 25-36. doi: 10.1111/j.1744-6198.2009.00124.x

Di Noia, J., \& Thompson, D. (2012). Processes of change for increasing fruit and vegetable consumption among economically disadvantaged African American adolescents. Eating behaviors, 13(1), 58-61. doi:10.1016/j.eatbeh.2011.10.001

DiClemente, C. C. (2003). Addiction and change: How addictions develop and addicted people recover. The Guilford Press.

DiClemente, C. C. (2017). O Modelo Transteórico: Implicações para a clínica e para a saúde pública. In: Oliveira, M.S., Boff, R.M., Cazassa, M.J., \& DiClemente, C.C (Eds.). Por que é tão dificil mudar? Contribuições do modelo transteórico de mudança do comportamento na prática clínica e na promoção de saúde. (pp. 23-33). Sinopsys.

Feoli, A. M. P., Ribeiro, E. C. T., Piovesan, C. H., Macagnan, F. E., Oliveira, M. S., \& Gustavo, A. (2018). Melhora do estilo de vida reduz o Índice de Castelli 1 em indivíduos com síndrome metabólica. Revista Saúde e Pesquisa, 11(3), 467-474. doi: 10.17765/1983-1870.2018v11n3p467-474 
Han, H., Gabriel, K. P., \& Kohl, H. W. (2015). Evaluations of validity and reliability of a transtheoretical model for sedentary behavior among college students. American journal of health behavior, 39(5), 601-609. doi:10.5993/AJHB.39.5.2

Kurita, G. P., \& Pimenta, C. A. D. M. (2003). Adesão ao tratamento da dor crônica: Estudo de variáveis demográficas, terapêuticas e psicossociais. Arq Neuropsiquiatr, 61(2-B), 416-25. doi: 10.1590/S0004-282X2003000300017

Ludwig, M. B. L., Bortolin, C., Bortolini, M., Boff, R. M., \& Oliveira, M. S. (2010a). Intervenção Grupal em pacientes com Síndrome Metabólica. Revista Brasileira de Terapias Cognitivas (Impresso), 6(1), 5-31,. doi:10.5935/18085687.20100002

Ludwig, M. W. B. (2012). Modelo Transteórico de Mudança de comportamento na síndrome metabólica: intervenções e fatores preditivos de mudança. (Tese de doutorado não publicada). http://tede2.pucrs.br/tede2/handle/tede/811

Ludwig, M. W. B. (2017). Modelo Transteórico de Mudança de comportamento (MTT): o que é e como se aplica? In M. S. Oliveira, R. M. Boff, M. J. Cazassa, \& C. DiClemente (Eds.). Por que é tão difícil mudar?: Contribuições do modelo transteórico de mudança na prática clínica e na promoção de saúde. (pp. 34-59). Sinopsys.

Ludwig, M. W. B., Boff, R. M., Susin, N., Bortolon, C., Silva, D. C., \& Oliveira, M.S. (2013, Setembro). Desenvolvimento de um protocolo de tratamento para pacientes com risco cardiovascular. Trabalho apresentado na V Jornada WP de Terapia Cognitiva, Porto Alegre.

Ludwig, M. W. B., Boff, R. M., Susin, N., Macagnan, F.E., Gustavo, A., Feoli, A.M.P. \& Oliveira, M.S. (2015, Abril). Programa de 12 sessões para tratamento da Síndrome Metabólica em adultos. Trabalho apresentado no X Congresso Brasileiro de Terapias Cognitivas, Porto de Galinhas. http://cbtc.fbtc.org. br/Edicao/2015/admin/trabalhosCBTC/IAS_XCBTC033.pdf

Ludwig, M. W. B., Strey, M. N., \& da Silva Oliveira, M. (2010b). Tratamentos manualizados: Psicólogos matemáticos? Revista Grifos, 19(28/29), 55-72.

Melnik, T.; Atallah, A. N. (2011). Psicologia baseada em evidências: Articulação entre a pesquisa e a prática clínica. In T. Melnik, \& A. N. Atallah (Eds.). Psicologia baseada em evidencias: Provas científicas da efetividade da psicoterapia (pp. 3-8). Santos.

Menezes, M. C., Bedeschi, L. B., dos Santos, L. C., \& Lopes, A. C. S. (2016). Interventions directed at eating habits and physical activity using the Transtheoretical Model: A systematic review. Nutricion hospitalaria, 33(5), 1194-1204. doi: $10.20960 /$ nh.586

Miller, W. R. \& Rollnick, S. (2001). Entrevista Motivacional Preparando as pessoas para a mudança de comportamentos aditivos ( 1 ed). Artmed.

Miller, W. R. \& Rollnick, S. (2013). Motivational Interview Helping people change (3 ed.). The Guilford Press.

Mostafavi, F., Ghofranipour, F., Feizi, A., \& Pirzadeh, A. (2015). Improving physical activity and metabolic syndrome indicators in women: A transtheoretical model-based intervention. International journal of preventive medicine, $6(1)$, 28-35. doi:10.4103/2008-7802.154382

Oliveira, M. S., Ludwig, M.W.B., \& Susin, N. (2013, Novembro, 2729). Protocolo de Intervenção baseado no Modelo Transteórico de mudança de comportamento - Importância da assertividade em um programa interdisciplinar. Trabalho apresentado no IV Seminário Internacional de Habilidades Sociais, Niterói, RS. http://www.rihs.ufscar.br/wp-content/uploads/2015/07/ ivsihs-anais.pdf

Oliveira, M. S., Ludwig, M.W.B., \& Susin, N. (2012, Agosto, 26-29). Sucesso no atendimento em grupo com base no modelo transteórico. Trabalho apresentado no VII Congresso
Iberoamericano de Psicologia Clínica y de la Salud. Córdoba, Argentina (Congresso). https://funveca.org/apicsa/congresosrealizados-por-apicsa/

Oliveira., V. Z, Gomes, W. B. (2004). Comunicação médicopaciente e adesão ao tratamento em adolescentes portadores de doenças orgânicas crônicas. Estudos de Psicologia, 9(3), 459-469.

Ott, U., Stanford, J. B., Greenwood, J. L., Murtaugh, M. A., Gren, L. H., Thiese, M. S., \& Hegmann, K. T. (2015). Stages of weight change among an occupational cohort. Journal of occupational and environmental medicine, 57(3), 270-276. doi:10.4103/2008-7802.154382

Prochascka, J. M., Prochascka, J. O., Johnson, S. S. (2006). Assessing readiness for adherence to treatment. In W. T. O'Donohue, \& E. R. Levensky (Eds.). Treatment adherence: A practical handobook for health care providers. Sage Publication

Prochaska, J. O., \& Velicer, W. F. (1997). The transtheoretical model of health behavior change. American Journal of Health Promotion, 12(1), 38-48.

Prochaska, J. O., DiClemente, C. C., \& Norcross, J. C. (1992). In search of how people change: Applications to addictive behavior. American Psychologist, 47, 102-114.

Prochaska, J. O., Redding, C. A., \& Evers, K. E. (2008). The Transtheoretical Model and Stages of Change. In K. Glanz, B. K. Rimer, \& K. Viswanath (Eds.). Health behavior and health education: Theory, research, and practice (4th ed). Jossey-Bass.

Reiners, A. A. O., Azevedo, R. C. S.; Vieira, M. A. , \& Arruda, A. L. G. (2008). Produção bibliográfica sobre adesão/nãoadesão de pessoas ao tratamento de saúde. Ciênc. saúde coletiva [online]., 13(suppl. 2), 2299-2306.

Rodrigues, V. S. (2013). Programa de tratamento para usuários de cocaína/crack baseado no modelo transteórico de mudança [Tese de doutorado, PUCRS). Repositório Institucional PUCRS. http://hdl.handle.net/10923/5644

Rollnick, S., Miller,W. R., \& Butler, C. C. (2009). Entrevista motivacional no cuidado à saúde: Ajudando pacientes a mudar comportamento. Artmed.

Romain, A. J., Bortolon, C., Gourlan, M., Carayol, M., Decker, E., Lareyre, O., \& Bernard, P. (2018). Matched or nonmatched interventions based on the transtheoretical model to promote physical activity. A meta-analysis of randomized controlled trials. Journal of Sport and Health Science, 7(1), 50-57.

Sanaeinasab, H., Saffari, M., Nazeri, M., Karimi Zarchi, A., \& Cardinal, B. J. (2013). Descriptive analysis of Iranian adolescents' stages of change for physical activity behavior. Nurs Health Sci, 15(3), 280-285. doi:10.1111/nhs. 12020

Santos, Z. M. S. A., Frota, M. A., Cruz, D. M., \& Holanda, S. D. O. (2005). Adesão do cliente hipertenso ao tratamento: Análise com abordagem interdisciplinar. Texto Contexto Enferm, 14(3), 332-40. doi: 10.1590/S0104-07072005000300003

Sharovsky, L. L., Perez, G. H., Romano, B. W., \& Lopes, H. F. (2004). A psicoterapia de grupo em pacientes portadores de síndrome metabólica. Rev. Soc. Cardiol. Estado de Säo Paulo, 14(4), 646-651.

Sociedade Brasileira de Cardiologia. (2005). I Diretriz Brasileira de Diagnóstico e Tratamento da Síndrome Metabólica. Arq Bras Cardiol, 84 (suppl. 1).

Susin, N., Boff, R. M., Ludwig, M. W. B., Souza, F. P., Silva, J. G., Feoli, A. M. P., Gustavo, A., Brilmann, M., \& Oliveira, M. S. (2014, Fevereiro). Tratamento Motivacional da Síndrome Metabólica: Um estudo de seguimento. Trabalho apresentado no X Congresso Nacional de Psicologia da Saúde, Porto.

Szupszynski, K. P. D. R. (2012) Estudo dos processos de mudança em usuários de substâncias psicoativas ilícita [Tese de 
doutorado, PUCRS]. Repositório Institucional PUCRS. http:// Velasquez, M., Maurer, G., Crouch, C., \& DiClemente, C. (2001). tede2.pucrs.br/tede2/handle/tede/810

Group treatment for substance abuse: a stages-of- change therapy manual. The Guilford Press.

Szupzinsky, K. P. D. R., Rodrigues, V. S., Ludwig, M. W. B.,

Souza, F. P., Oliveira, M. S., Boff, R. M., \& Susin, N. (2013, Wu, Y. K., \& Chu, N. F. (2015). Introduction of the transtheoretical Julho, 22-25). Os desafios de um trabalho interdisciplinar: como motivar os pacientes para mudança de comportamento. model and organizational development theory in weight management: A narrative review. Obesity research \& clinical Trabalho apresentado no 7th World Congress of Behavioral practice, 9(3), 203-213. doi:10.1016/j.orcp.2014.12.00 and Cognitive Therapies, Lima. 